\title{
Regulation of mammary hormone receptor metabolism by a retroviral envelope protein
}

\section{F F Bolander Jr}

Department of Biological Sciences, University of South Carolina, Columbia, South Carolina 29208, USA

\begin{abstract}
In a previous study, the envelope protein (gp52) of the mouse mammary tumour virus (MMTV) was shown to facilitate mammary gland differentiation by increasing prolactin (PRL) receptors via increased receptor synthesis and via the redistribution of existing receptors from an internal pool. In this study, receptors for other hormones known to affect mammary gland metabolism were investigated. Epidermal growth factor (EGF) stimulates mammary epithelial growth and inhibits differentiation; its receptor is rapidly and dramatically down-regulated by gp52. This is accomplished by its internalization and by decreasing its half-life
\end{abstract}

from $27 \mathrm{~h}$ to $2 \cdot 4 \mathrm{~h}$. Surprisingly, it also increased EGF receptor synthesis, although this effect was not great enough to overcome receptor downregulation. In contrast, gp52 did not affect the distribution, half-life or synthesis of the insulin receptor. These results demonstrate that MMTV can enhance mammary differentiation by coordinately regulating several hormone receptors: specifically, it can increase the number of receptors for PRL, a differentiative hormone, while decreasing the number of receptors for EGF, a growth/antidifferentiative hormone.

Fournal of Molecular Endocrinology (1998) 21, 161-168

\section{INTRODUCTION}

The mouse mammary tumour virus (MMTV) is a retrovirus that is propagated from mother to pups via the milk (Nandi \& McGrath 1973). Although it is oncogenic, the MMTV genome does not contain any oncogenes, and tumours only occur after a long latency period (van Leeuwen \& Nusse 1995). As such, mammary growth is a late indirect effect of the MMTV; instead, it is mammary differentiation and lactation that is critical for the propagation of the virus. To facilitate its own reproduction, the MMTV envelope protein, gp52, binds to the mammary cell surface and enhances the epithelial sensitivity to prolactin (PRL), a differentiative hormone (Bolander 1994a). This change in responsiveness is primarily accomplished by increasing PRL receptors via increased receptor synthesis and recruitment of PRL receptors from an intracellular pool (Bolander et al. 1997).

The question arises as to whether this is an isolated effect of the virus or whether it is part of a concerted programme to enhance mammary differentiation. To explore this question, the effects of gp52 on the metabolism of other hormone receptors were examined. In particular, two hormone receptors with totally different functions, as compared with the differentiative role of PRL receptors, were studied: the epidermal growth factor (EGF) receptor, which mediates growth, and the insulin receptor, which is responsible for the maintenance of general metabolism.

\section{MATERIALS AND METHODS}

\section{Materials}

Mouse EGF (lot 908374) was purchased from Collaborative Biomedical Products (Bedford, MA, USA), and crystalline porcine insulin (lot 092WW6) was a gift from Eli Lilly Company (Indianapolis, IN, USA). Cortisol, tri-iodothyronine ( $\left.\mathrm{T}_{3}\right)$, Hepes, cycloheximide, lactoperoxidase, BSA, normal mouse serum, goat anti-mouse immunoglobulin G and Dulbecco's modified Eagle's medium without cysteine or methionine were obtained from Sigma Chemical Company (St Louis, MO, USA). Medium 199 with Earle's salts was from Grand Island Biological Company (Grand Island, NY, USA) and collagenase type I (179 U/mg) was purchased from Worthington Biochemicals (Freehold, NJ, USA). Monoclonal antibodies to the mouse EGF receptor (lot 2) and insulin receptor (lot 2) were obtained from Transduction 
Laboratories (Lexington, KY, USA), and reagents for SDS-PAGE were purchased from Bio-Rad (Richmond, CA, USA). A mixture of $\left[{ }^{35} \mathrm{~S}\right]$ cysteine and $\left[{ }^{35} \mathrm{~S}\right]$ methionine $\left(\operatorname{Tran}^{35} \mathrm{~S}-\mathrm{Label} ;>1000 \mu \mathrm{Ci} /\right.$ mmol) was purchased from ICN Pharmaceuticals (Costa Mesa, CA, USA) and $\mathrm{Na}^{125} \mathrm{I}$ (carrier-free) was from New England Nuclear (Boston, MA, USA).

gp52, the MMTV envelope protein, was prepared in my laboratory by the method of Marcus et al. (1979); milk from C3H/HeN MMTV ${ }^{+}$mice was used as the source of the virus. No contamination with other proteins could be detected on overloaded gels (Bolander et al. 1997). Polyclonal antibodies to gp52 were also produced in my laboratory as described in Bolander \& Blackstone (1990).

\section{Animals and tissue preparation}

Virgin mice $\left(\mathrm{C} 3 \mathrm{H} / \mathrm{HeN} \mathrm{MMTV}{ }^{+}\right.$and $\left.\mathrm{MMTV}^{-}\right)$ were obtained from the Frederick Cancer Research Facility (Frederick, MD, USA). The mice were killed by cervical dislocation. After the lymph nodes had been removed from the fourth pair of glands, explants were prepared under sterile conditions, as previously described (Juergens et al. 1965). Explants were cultured on siliconized lens paper in Medium 199 containing $20 \mathrm{mM}$ Hepes (pH 7.6) and combinations of the following reagents, as required by the individual experiment: cycloheximide $(10 \mu \mathrm{g} /$ $\mathrm{ml})$, insulin $(1 \mu \mathrm{g} / \mathrm{ml})$, cortisol $(1 \mu \mathrm{g} / \mathrm{ml}), \mathrm{T}_{3}(65 \mathrm{pg} /$ $\mathrm{ml})$ and/or gp52 $(1 \mu \mathrm{g} / \mathrm{ml})$. The concentration of gp52 was chosen so as to saturate the gp52 receptor (Bolander \& Blackstone 1991). The tissue was incubated under air at $37^{\circ} \mathrm{C}$, and the medium was changed daily.

\section{Cell isolation and membrane fractionation}

EGF and insulin receptors were measured on an epithelial cell-enriched fraction isolated from mammary explants, as previously described (Vonderhaar et al. 1973). Briefly, the tissue was finely minced and digested with collagenase $(1.5 \mathrm{mg} / \mathrm{ml}$ of Medium 199 containing $20 \mathrm{mM}$ Hepes (pH 7·6) and 4\% (w/v) BSA) at $37^{\circ} \mathrm{C}$. During this incubation, the tissue fragments were pipetted through successively smaller bore pipettes. After $30 \mathrm{~min}$, the cells were centrifuged at $800 \boldsymbol{g}$ for $30 \mathrm{~s}$ and washed three times in Medium 199 containing $20 \mathrm{mM}$ Hepes (pH 7·6) and $2 \% \mathrm{BSA}$. The resulting preparation contained small pieces of ducts and end buds, rather than individual epithelial cells. In addition to minimizing damage to the epithelium, this technique easily separates the epithelial aggregates from isolated fibroblasts which sediment more slowly.
When EGF and insulin binding in membrane fractions was to be assessed, the epithelial cells were lysed and fractionated using the two-phase system of Brunette \& Till (1971). This technique separates the plasma membrane from other fractions, referred to here as microsomes. Because receptor redistribution can occur quickly (Bolander 1994b), a $30 \mathrm{~min}$ time point was chosen for the determination of both EGF and insulin receptors; the distribution of EGF receptors was also measured after 3 days to determine whether any of the observed changes persisted. However, because the insulin receptor can be regulated by both insulin and glucocorticoids (Knutson et al. 1982), these hormones were omitted from the medium used for insulin receptor studies. Since the tissue remained viable for at least several hours without insulin and cortisol, the $30 \mathrm{~min}$ time point and the receptor half-life studies were not affected by this omission. However, the 3 day time point was not possible in the insulin receptor experiments.

\section{EGF and insulin receptor assay}

EGF and insulin were iodinated by a modification (Bolander \& Fellows 1975) of the lactoperoxidase method of Miyachi et al. (1972). The resulting ${ }^{125}$ I-labelled hormone was used in binding studies, as previously described (Bolander 1984). Binding was saturable, and $80-90 \%$ of the tracer could be dissociated upon dilution, after which the receptor could be recovered and shown to rebind approximately the same amount of ${ }^{125}$ I-labelled hormone, suggesting that the receptor was not damaged during the $2 \mathrm{~h}$ incubation. The radioactivity in the supernatant could be completely precipitated by trichloroacetic acid after $2 \mathrm{~h}$, suggesting that it too was not degraded.

For the receptor half-lives, mammary explants were cultured in Medium 199 with insulin, cortisol and cycloheximide $(10 \mu \mathrm{g} / \mathrm{ml})$; all additives were co-mixed simultaneously. At various time points, cells were isolated and total receptors were measured on the plasma membrane as described above.

Protein was determined by the method of Lowry et al. (1951), and binding data were analysed by the method of Scatchard (1949). Because of the low epithelial content of mouse mammary glands, five to six animals were required to generate enough cells to construct a single Scatchard plot.

\section{Synthesis of EGF and insulin receptors}

Receptor synthesis was determined by incubating explants in $2 \mathrm{ml}$ Dulbecco's modified Eagle's 
medium deficient in cysteine and methionine but containing $20 \mathrm{mM}$ Hepes (pH 7.6). The explants were cultured with or without gp52; after $4 \mathrm{~h}$, $100 \mu \mathrm{Ci}$ of a mixture of $\left[{ }^{35} \mathrm{~S}\right]$ cysteine and $\left[{ }^{35} \mathrm{~S}\right]$ methionine was added and the tissue cultured for $2 \mathrm{~h}$ more. This time period was chosen because preliminary experiments showed that there was no effect of gp52 on the synthesis of either the insulin or EGF receptors before $4 \mathrm{~h}$. The explants were then homogenized and the receptors immunoprecipitated as previously described (Ono \& Oka 1980). The precipitate was dissolved in PBS containing $4 \mathrm{M}$ deionized urea and $2 \mathrm{M} \beta$ mercaptoethanol and electrophoresed on SDSpolyacrylamide gels by the method of Weber \& Osborn (1969). The major radioactive bands corresponded to the known molecular masses for the $\mathrm{EGF}$ receptor $(170 \mathrm{kDa})$ and the $\alpha$ and $\beta$ chains of the insulin receptor $(95$ and $135 \mathrm{kDa}$ respectively). These bands were excised, eluted and counted for radioactivity.

\section{RESULTS}

EGF receptor levels in mammary glands from pregnant mice fluctuate markedly, first rising in early pregnancy and then declining later; these low levels then persist during lactation (Edery et al. 1985). Virgin mice were chosen for this study, because EGF receptor levels in glands from these animals are stable, easily measured and uninfluenced by the high concentrations of hormones associated with pregnancy and lactation.

All Scatchard plots of the EGF receptor data were linear (Fig. 1) and the affinity constants did not differ significantly among experimental groups using ANOVA $(69 \pm 12 \mathrm{pM})$. In mammary epithelial cells from MMTV $^{-}$mice, nearly $90 \%$ of the EGF receptors were located on the cell surface (Fig. 2). Within $30 \mathrm{~min}$ of exposure to gp52, these plasma membrane receptors decreased by one-third. At the same time, microsomal EGF receptors increased by a similar amount, suggesting that the receptors had been internalized. However, by 3 days the microsomal EGF receptors had returned to baseline values, while the plasma membrane receptors continued to fall. This suggests that the EGF receptors were not being recycled to the cell surface but were destroyed. This result is consistent with reports that the EGF receptor does not recycle in many tissues, leading to a prolonged period of down-regulation (Das 1982).

Since EGF has similar effects on its own receptor (Haigler et al. 1978, Schlessinger et al. 1978) and since gp52 was purified from viruses obtained from

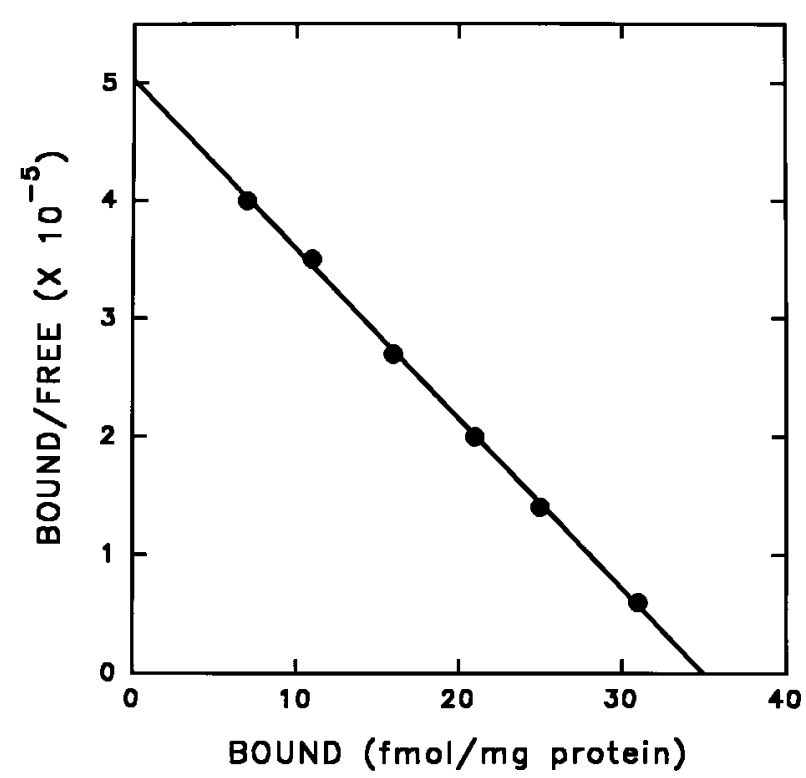

FIGURE 1. Representative Scatchard plot of EGF receptors on the plasma membrane of uncultured epithelial cells from $\mathrm{MMTV}^{-}$mice.

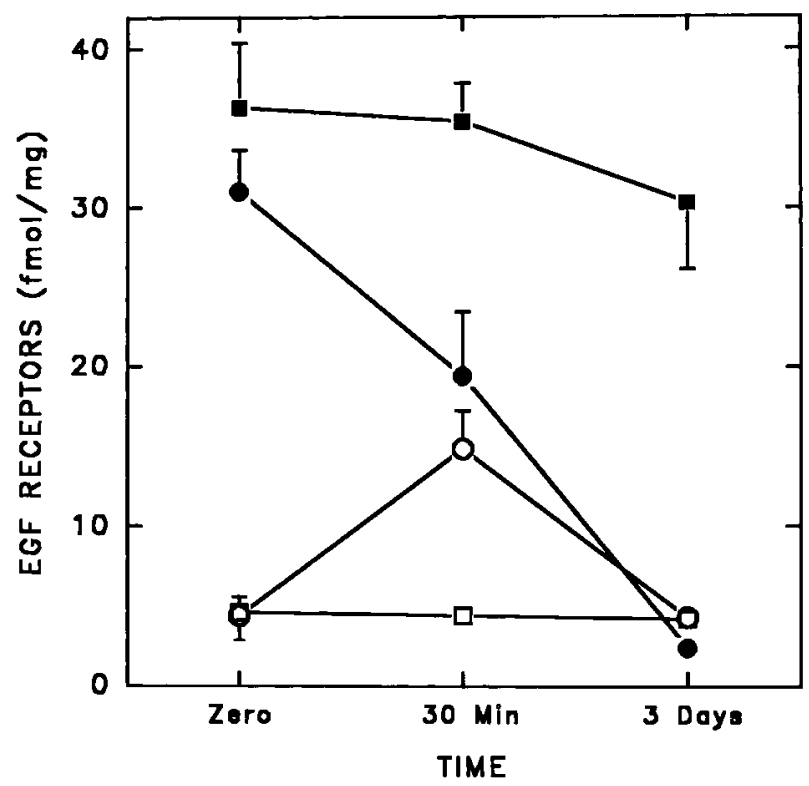

FIGURE 2. EGF receptor redistribution in mammary epithelium from MMTV $^{-}$mice. Mammary explants were incubated either with $(\bigcirc, \boldsymbol{O})$ or without $(\square, \boldsymbol{\square})$ gp52, and EGF receptors were measured in plasma membranes $(\boldsymbol{O}, \boldsymbol{\square})$ or microsomes $(\bigcirc, \square)$ at the indicated times. Values are means \pm s.E.M. $(n=4)$.

milk, which also contains EGF (Gresik et al. 1984), the gp52 used in this study was evaluated for possible contamination with EGF. If the effects of gp52 were due to contaminating EGF, they should be blocked by EGF receptor antibodies. Table 1 
TABLE 1. EGF receptors on the plasma membranes of mammary epithelial cells after a $30 \mathrm{~min}$ incubation with the indicated compounds. Antibodies were added to a final concentration of $1 \mu \mathrm{g} / \mathrm{ml}$ medium. Values are means \pm S.E.M. $(n=4)$

\begin{tabular}{|c|c|c|}
\hline \multirow[b]{2}{*}{ Addition } & \multicolumn{2}{|c|}{$\begin{array}{l}\text { EGF receptors } \\
(\mathrm{fmol} / \mathrm{mg}\end{array}$} \\
\hline & & \\
\hline None & $33 \cdot 7 \pm 3 \cdot 4$ & \\
\hline gp52 (1 $\mu \mathrm{g} / \mathrm{ml})$ & $15 \cdot 6 \pm 2 \cdot 4$ & $<0 \cdot 005$ \\
\hline EGF $(1 \mu \mathrm{g} / \mathrm{ml})$ & $17 \cdot 1 \pm 3 \cdot 2$ & $<0 \cdot 01$ \\
\hline $\mathrm{EGF}+\mathrm{EGF}$ receptor antibodies & $34 \cdot 2 \pm 4 \cdot 0$ & NS \\
\hline gp52+EGF receptor antibodies & $17 \cdot 3 \pm 2 \cdot 0$ & $<0 \cdot 01$ \\
\hline gp52+gp52 antibodies & $33 \cdot 2 \pm 2 \cdot 5$ & NS \\
\hline
\end{tabular}

NS, not significant.

TABLE 2. Effect of EGF and gp52 on ${ }^{125}$ I-labelled EGF binding to mammary epithelial cells. EGF and gp52 were added to a final concentration of $1 \mu \mathrm{g} / \mathrm{ml}$ medium. Values are means \pm S.E.M. $(n=4)$

\begin{tabular}{|c|c|c|}
\hline \multirow[b]{2}{*}{ Addition } & \multicolumn{2}{|c|}{${ }^{125}$ I-labelled EGF bound } \\
\hline & & \\
\hline None & $9771 \pm 1221$ & \\
\hline EGF & $196 \pm 29$ & $<0 \cdot 001$ \\
\hline gp52 & $9382 \pm 967$ & NS \\
\hline
\end{tabular}

NS, not significant.

shows that, although these antibodies can inhibit EGF-induced receptor down-regulation, they cannot prevent the effects of gp52. However, antibodies specific to gp52 can block the actions of gp52. In addition, gp52 is unable to displace ${ }^{125}$ I-labelled EGF from EGF receptors (Table 2). Therefore the effect of gp52 on EGF receptors is not due to EGF contamination.

The redistribution of EGF receptors induced by gp52 is further supported by studies on the half-life of the EGF receptor (Fig. 3). In unstimulated epithelium, receptor levels declined logarithmically in the presence of cycloheximide; the estimated half-life was $27 \mathrm{~h}$, a value similar to that reported by Edery et al. (1989) in this same tissue. However, in the presence of gp52, the receptor half-life fell dramatically to only $2 \cdot 4 \mathrm{~h}(P<0 \cdot 01)$.

Surprisingly, gp52 stimulated EGF receptor synthesis 5 - to 6 -fold by $6 \mathrm{~h}$ (Fig. 4). This seeming paradox has also been observed during EGF-induced down-regulation: although EGF profoundly down-regulates its own receptor, it simultaneously elevates EGF receptor mRNA 5-fold (Clark et al. 1985, Earp et al. 1986, Bjorge \& Kudlow 1987). It has been postulated that this

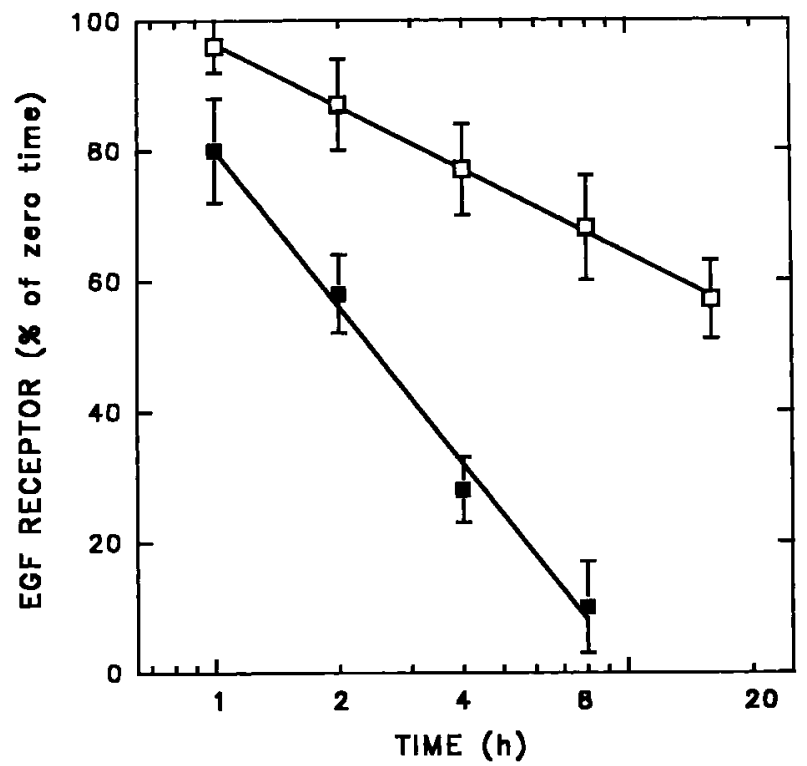

FIGURE 3. EGF receptor half-life in mammary explants from MMTV ${ }^{-}$mice. Mammary explants were cultured with cycloheximide $(10 \mu \mathrm{g} / \mathrm{ml})$ with $(\boldsymbol{\square})$ or without $(\square)$ gp52, and EGF receptors were measured at the indicated times. Values are means \pm S.E.M. $(n=4)$.

effect primes the cell so that it can rapidly replenish its EGF receptor numbers after EGF has been removed.

Unlike the EGF receptor plots, the Scatchard plots for the insulin receptor data were curvilinear, confirming the reports of others (Inagaki \& Kohmoto 1982, Bolander 1984). Because of the questionable physiological relevance of the lowaffinity sites, only the high-affinity receptors were examined. The affinity constants for these latter sites did not differ significantly among the experimental groups $(360 \pm 30 \mathrm{pM})$; therefore, only receptor numbers are given. Like the EGF receptors, insulin receptors were predominantly located in the plasmalemma (Fig. 5). However, in contrast with the EGF receptors, the insulin receptors did not undergo a redistribution in response to gp52. Furthermore, there was no significant change in insulin receptor half-life: $7 \cdot 5$ vs $8.4 \mathrm{~h}$ for epithelium cultured with and without gp 52 respectively (Fig. 6). Finally, gp52 had no effect on insulin receptor synthesis (Fig. 4).

\section{DISCUSSION}

As noted in the Introduction, MMTV propagation is dependent upon lactation, since this is the route by which the pups become infected. Furthermore, 


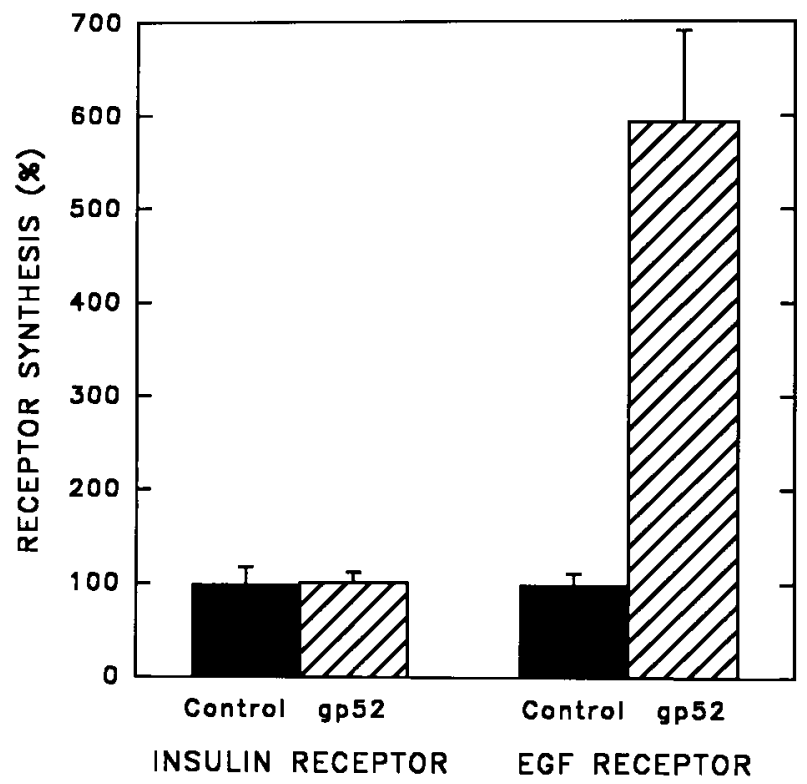

FIGURE 4. Insulin and EGF receptor synthesis by mammary explants. Explants were exposed to

${ }^{35} \mathrm{~S}$-labelled amino acids during 4-6 h of culture with or without gp52. Receptors were then immunoprecipitated, electrophoresed on SDS-polyacrylamide gels, excised and counted for radioactivity. Values are means \pm s.E.M. $(n=4)$.

MMTV production begins in late pregnancy, when morphological development is nearing completion and milk production is imminent (Muñoz \& Bolander 1989). At this time, the MMTV is shed into both the milk and the bloodstream (Nandi \& McGrath 1973), from which the envelope protein, gp52, can activate its receptor. Previous studies from this laboratory have shown that this interaction can facilitate biochemical differentiation in the mammary gland by elevating PRL receptors (Bolander et al. 1997). The data from this work demonstrate that gp52 can also decrease EGF receptors.

How can a change in EGF receptors affect MMTV propagation? In many tissues, growth factors and differentiative factors oppose each other. For example, in mouse mammary explants, EGF inhibits casein synthesis, a marker for biochemical differentiation (Taketani \& Oka 1983). In addition, EGF receptors in mammary epithelium decrease during late pregnancy and lactation (Edery et al. 1985), when PRL receptor levels are rising and biochemical differentiation is commencing (Holcomb et al. 1976). However, subsequent studies have complicated the interpretation of these earlier works, suggesting that the inhibitory effects in vitro may have been dependent upon the presence of

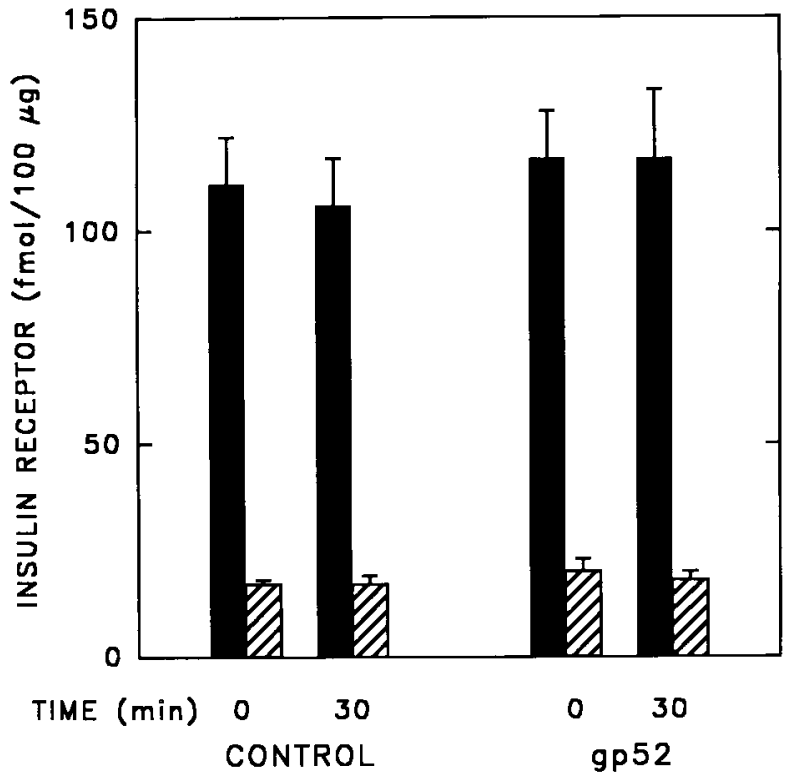

FIGURE 5. Insulin receptor redistribution in mammary epithelium from MMTV $^{-}$mice. Mammary explants were incubated either with or without gp52 and insulin receptors were measured in plasma membranes (solid bars) or microsomes (hatched bars) at zero time and $30 \mathrm{~min}$. Values are means \pm s.E.M. $(n=4)$.

other hormones (Vonderhaar \& Nakhasi 1986, Sankaran \& Topper 1987). Furthermore, EGF is known to enhance morphological differentiation in mouse glands, i.e. lobuloalveolar development (Tonelli \& Sorof 1980, Vonderhaar 1987). Finally, sialoadenectomized mice, which cannot synthesize normal amounts of EGF (Okamoto \& Oka 1984), and homozygous waved-2 mutant mice, which have mutant EGF receptors and cannot respond to EGF (Fowler et al. 1995), have impaired lactation. The general consensus is that EGF is necessary for mammary epithelial proliferation, which affects the magnitude of lactation, but that EGF is detrimental to actual milk production (Forsyth 1989, Oka et al. 1991). As noted above, blood MMTV levels do not rise until late pregnancy, when it could block the late anti-differentiative effects of EGF without affecting the earlier effects of EGF on mammary growth. As such, MMTV enhances mammary differentiation by increasing the receptors for PRL, a differentiative hormone, while decreasing those for EGF at a time when its anti-differentiative effects would be manifest.

Other viral proteins have also targeted EGF receptor metabolism. In contrast with the MMTV, the human papillomavirus is dependent upon cellular replication for its propagation. To this end, the $\mathrm{E} 5$ protein of this virus binds to and inhibits 


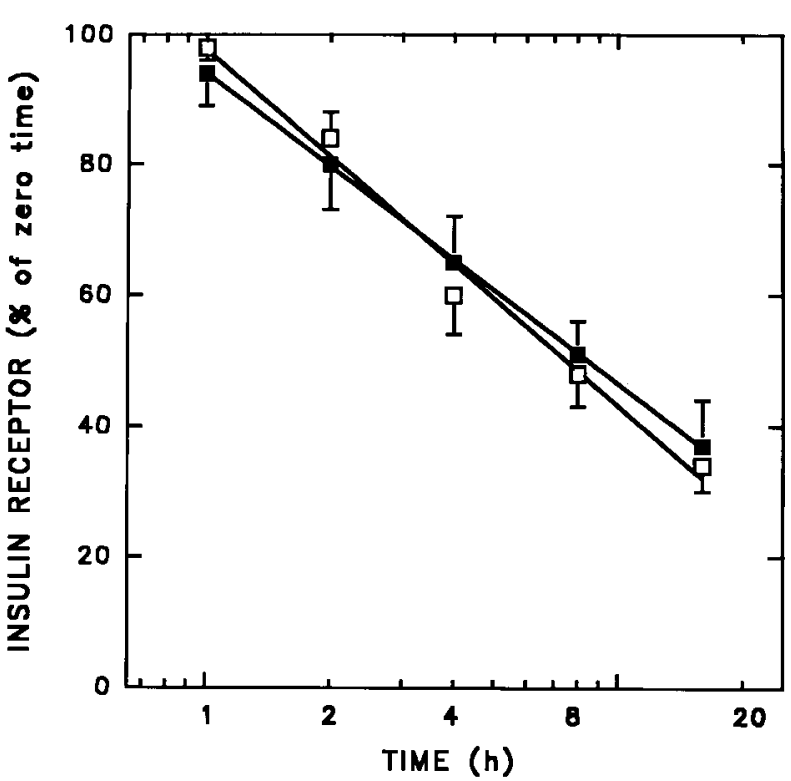

FIGURE 6. Insulin receptor half-life in mammary explants from MMTV ${ }^{-}$mice. Mammary explants were cultured with cycloheximide $(10 \mu \mathrm{g} / \mathrm{ml})$ with $(\boldsymbol{\square})$ or without $(\square)$ gp52, and insulin receptors were measured at the indicated times. Values are means \pm S.E.M. $(n=4)$.

the vacuolar $\mathrm{H}^{+}$-ATPase, which is required for the proper acidification of endosomes (Straight et al. 1995). As a result, the internalized EGF receptor escapes destruction and is recycled to the cell surface where it mediates cellular proliferation.

The function of insulin is often described non-specifically as 'maintenance of viability'; as such, one might not expect it to have a specific role in either growth or differentiation. However, like EGF, the function of insulin in the mammary gland is complicated: it is specifically required for the induction of milk proteins, and insulin-like growth factors cannot substitute for it (Bolander et al. 1981, Nicholas \& Topper 1983). In addition, the insulin receptor increases during pregnancy and remains increased during lactation (Inagaki \& Kohmoto 1982), suggesting an important role in differentiation. However, its receptor does not appear to be a target of the MMTV; receptor synthesis, distribution and half-life are all unaffected by gp52. Apparently, the effects of insulin on differentiation are not sufficiently specific or limiting to favour the evolutionary acquisition of regulatory controls over these receptors by the MMTV.

Many viruses use their cellular receptors not only to identify target tissues and then gain entry, but also to activate physiological functions that facilitate viral propagation. Most viruses require ongoing cellular replication for their propagation and choose their receptors accordingly, e.g. the vaccinia virus binds to and activates the EGF receptor (King et al. 1986), while the papillomavirus binds to and activates the platelet-derived growth factor receptor (Kulke \& DiMaio 1991). In contrast, the propagation of the MMTV is dependent upon the differentiation of the mammary epithelium, and it employs a rather sophisticated strategy to aid its own cause. Although its envelope protein does not directly bind to either the PRL or EGF receptors, activation of the binding protein for gp52 does affect these receptors: it increases the number of PRL receptors and decreases the number of EGF receptors, thereby enhancing differentiation by facilitating the action of PRL, a lactogenic hormone, and impairing the effects of EGF, a growth/anti-differentiation hormone.

\section{ACKNOWLEDGEMENTS}

This work was supported in part by Public Health Service grant CA 42009 from the National Cancer Institute. The technical assistance of William McAmis is gratefully appreciated.

\section{REFERENCES}

Bjorge JD \& Kudlow JE 1987 Epidermal growth factor receptor synthesis is stimulated by phorbol ester and epidermal growth factor. Fournal of Biological Chemistry 262 6615-6622.

Bolander FF 1984 Enhanced hormonal responsiveness in mammary glands from parous mice: molecular mechanisms. Molecular and Cellular Endocrinology 35 221-227.

Bolander FF $1994 a$ The effect of mouse mammary tumor virus (MMTV) receptor activation on mammary epithelial cell sensitivity toward prolactin. Biochemical and Biophysical Research Communications 205 524-528.

Bolander FF $1994 b$ Regulation of the mouse mammary tumor virus receptor by phosphorylation and internalization in mammary epithelial cells. Fournal of Cellular Physiology 161 124-128.

Bolander FF \& Fellows RE 1975 Growth hormone covalently bound to Sepharose or glass: analysis of ligand release rates and characterization of soluble radiolabeled products. Biochemistry 14 2938-2943.

Bolander FF \& Blackstone ME 1990 Developmental and hormonal regulation of a mouse mammary tumour virus glycoprotein in normal mouse mammary epithelium. Fournal of Molecular Endocrinology 4 101-106.

Bolander FF \& Blackstone ME 1991 Tissue distribution of the cellular binding protein for the mouse mammary tumour virus. Fournal of Molecular Endocrinology 7 169174 . 
Bolander FF, Nicholas KR, Van Wyk JJ \& Topper YJ 1981 Insulin is essential for accumulation of casein mRNA in mouse mammary epithelial cells. Proceedings of the National Academy of Sciences of the USA 78 5682-5684.

Bolander FF, Ginsburg E \& Vonderhaar BK 1997 The regulation of mammary prolactin receptor metabolism by a retroviral envelope protein. Fournal of Molecular Endocrinology 19 131-136.

Brunette DM \& Till JE 1971 A rapid method for the isolation of L-cell surface membranes using an aqueous two-phase polymer system. Fournal of Membrane Biology 5 215-224.

Clark AJL, Ishii S, Richert N, Merling GT \& Pastan I 1985 Epidermal growth factor regulates the expression of its own receptor. Proceedings of the National Academy of Sciences of the USA $828374-8378$.

Das M 1982 Epidermal growth factor: mechanisms of action. International Review of Cytology 78 233-256.

Earp HS, Austin KS, Blaisdell J, Rubin RA, Nelson KG, Lee LW \& Grisham JW 1986 Epidermal growth factor (EGF) stimulates EGF receptor synthesis. Fournal of Biological Chemistry 261 4777-4780.

Edery M, Pang K, Larson L, Colosi T \& Nandi S 1985 Epidermal growth factor receptor levels in mouse mammary glands in various physiological states. Endocrinology 117 405-411.

Edery M, Pang K, Larson L \& Nandi S 1989 Turnover of epidermal growth factor binding sites in mouse mammary epithelial cells. Biomedicine and Pharmacotherapy $\mathbf{4 3}$ 361-368.

Forsyth IA 1989 Growth factors in mammary gland function. Fournal of Reproduction and Fertility 85 759-770.

Fowler KJ, Walker F, Alexander W, Hibbs ML, Nice EC, Bohmer RM, Mann GB, Thumwood C, Maglitto R, Danks JA, Chetty R, Burgess AW \& Dunn AR 1995 A mutation in the epidermal growth factor receptor in waved-2 mice has a profound effect on receptor biochemistry that results in impaired lactation. Proceedings of the National Academy of Sciences of the USA 92 1465-1469.

Gresik EW, van der Noen H \& Barka T 1984 Transport of ${ }^{125}$ I-EGF into milk and effect of sialoadenectomy on milk EGF in mice. American Fournal of Physiology 247 E349-E354.

Haigler H, Ash JF, Singer SJ \& Cohen S 1978 Visualization by fluorescence of the binding and internalization of epidermal growth factor in human carcinoma cells A-431. Proceedings of the National Academy of Sciences of the USA 75 3317-3321.

Holcomb HH, Costlow ME, Buschow RA \& McGuire WL 1976 Prolactin binding in rat mammary gland during pregnancy and lactation. Biochimica et Biophysica Acta 428 104-112.

Inagaki Y \& Kohmoto K 1982 Changes in Scatchard plots for insulin binding to mammary epithelial cells from cycling, pregnant, and lactating mice. Endocrinology 110 176-182.

Juergens WC, Stockdale FE, Topper YJ \& Elias JJ 1965 Hormonal-dependent differentiation of mouse mammary gland in vitro. Proceedings of the National Academy of Sciences of the USA 54 629-634.

King CS, Cooper JA, Moss B \& Twardzik DR 1986 Vaccinia virus growth factor stimulates tyrosine protein kinase activity of A431 cell epidermal growth factor receptors. Molecular and Cellular Biology 6 332-336.

Knutson VP, Ronnett GV \& Lane MD 1982 Control of insulin receptor level in 3T3 cells: effect of insulin-induced downregulation and dexamethasone-induced up-regulation on rate of receptor inactivation. Proceedings of the National Academy of Sciences of the USA 79 2822-2826.
Kulke R \& DiMaio D 1991 Biological properties of the deer papillomavirus E5 gene in mouse $\mathrm{C} 127$ cells: growth transformation, induction of DNA synthesis, and activation of the platelet-derived growth factor receptor. Fournal of Virology 65 4943-4949.

van Leeuwen F \& Nusse R 1995 Oncogene activation and oncogene cooperation in MMTV-induced mouse mammary cancer. Seminars in Cancer Biology 6 127-133.

Lowry OH, Rosebrough NJ, Farr AL \& Randall RJ 1951 Protein determination with the Folin phenol reagent. Fournal of Biological Chemistry 193 265-275.

Marcus SL, Kopelman R \& Sarkar NH 1979 Simultaneous purification of murine mammary tumor virus structural proteins: analysis of antigenic reactivities of native gp34 by radioimmunocompetition assays. Fournal of Virology 31 341-349.

Miyachi Y, Vaitukaitis JL, Nieschlag E \& Lipsett MB 1972 Enzymatic radioiodination of gonadotropins. Fournal of Clinical Endocrinology and Metabolism 34 23-28.

Muñoz B \& Bolander FF 1989 Prolactin regulation of mouse mammary tumor virus (MMTV) expression in normal mouse mammary epithelium. Molecular and Cellular Endocrinology 62 23-29.

Nandi S \& McGrath CM 1973 Mammary neoplasia in mice. Advances in Cancer Research 17 353-414.

Nicholas KR \& Topper YJ 1983 Anti-insulin receptor serum mimics the developmental role of insulin in mouse mammary explants. Biochemical and Biophysical Research Communications 111 988-993.

Oka T, Yoshimura M, Lavandero S, Wada K \& Ohba Y 1991 Control of growth and differentiation of the mammary gland by growth factors. Fournal of Dairy Science $\mathbf{7 4}$ $2788-2800$.

Okamoto S \& Oka T 1984 Evidence for physiological function of epidermal growth factor: Pregestational sialoadenectomy of mice decreases milk production and increases offspring mortality during lactation period. Proceedings of the National Academy of Sciences of the USA 81 6059-6063.

Ono M \& Oka T 1980 The differential actions of cortisol on the accumulation of $\alpha$-lactalbumin and casein in midpregnant mouse mammary gland in culture. Cell 19 473-480.

Sankaran L \& Topper YJ 1987 Is EGF a physiological inhibitor of mouse mammary casein synthesis? Unphysiological responses to pharmacological levels of hormones. Biochemical and Biophysical Research Communications 146 121-125.

Scatchard G 1949 The attractions of proteins for small molecules and ions. Annals of the New York Academy of Sciences 51 660-672.

Schlessinger J, Shechter Y, Willingham MC \& Pastan I 1978 Direct visualization of binding, aggregation, and internalization of insulin and epidermal growth factor on living fibroblastic cells. Proceedings of the National Academy of Sciences of the USA 75 2659-2663.

Straight SW, Herman B \& McCance DJ 1995 The E5 oncoprotein of human papillomavirus type 16 inhibits the acidification of endosomes in human keratinocytes. Fournal of Virology 69 3185-3192.

Taketani Y \& Oka T 1983 Possible physiological role of epidermal growth factor in the development of the mouse mammary gland during pregnancy. FEBS Letters 152 256-260.

Tonelli QJ \& Sorof S 1980 Epidermal growth factor requirement for development of cultured mammary gland. Nature 285 250-252.

Vonderhaar BK 1987 Local effects of EGF, $\alpha$-TGF, and EGF-like growth factors on lobuloalveolar development of 
the mouse mammary gland in vivo. Fournal of Cellular Physiology 132 581-584.

Vonderhaar BK \& Nakhasi HL 1986 Bifunctional activity of epidermal growth factor on $\alpha$ - and $\kappa$-casein gene expression in rodent mammary glands in vitro. Endocrinology 119 1178-1184.

Vonderhaar BK, Owens IS \& Topper YJ 1973 An early effect of prolactin on the formation of $\alpha$-lactalbumin by mouse mammary epithelial cells. Fournal of Biological Chemistry 248 467-471.

Weber K \& Osborn M 1969 The reliability of molecular weight determinations by dodecyl sulfate-polyacrylamide gel electrophoresis. Fournal of Biological Chemistry 244 4406-4412.

REVISED MANUSCRIPT RECEIVED 13 January 1998 